\title{
Ground-Source Heat Pumps and Energy Saving
}

\author{
Mohamad Kharseh \\ Willy's CleanTech AB, PARK 124 Karlstad, \\ Sweden
}

\section{Introduction}

The global warming itself and its consequences cause considerable problems. It results in extreme climate events such as droughts, floods, or hurricanes, which are expected to become more frequent. This puts extra strain on people and has great impact on public health and life quality especially in poor countries.

Internationally, there is a political understanding that global warming (or climate change) is the main challenge of the world for decades to come. Thus, all states must work together in order to overcome climatic change consequences.

Although, studies suggest that there is indeed relationship between solar variability and global warming (Lean and Rind, 2001), two causes of the warming have been suggested:

1. related to the accumulation of greenhouse gases in the Earth's atmosphere;

2. related to heat emissions (Nordell, 2003, Nordell and Gervet, 2009).

This implies that current warming is anthropogenic and caused by human activities, i.e. global use of non-renewable energy. So far, the total global energy consumption has already exceeded $15 \cdot 10^{10} \mathrm{MWh}$ /year and it is projected to have an annual growth rate about $1.4 \%$ until 2020 (EIA, 2010).

Much of the energy used worldwide is mainly supplied by fossil fuels ( $\sim 5 \%$ of the global energy demand while renewable energy sources supply only about $6 \%$ ) (Moomaw et al., 2011, Jabder et al., 2011, Jaber et al., 2011). Owing to global dependence on oil fuels has resulted in a daily oil consumption of 87.7 million barrels (Mbbl), Fig. 1 (IEA, 2010, EIA, 2007). Consequently, about $3.10^{10}$ ton of carbon dioxide emissions are annually emitted into the atmosphere. In other word, for each consumed $\mathrm{kWh}$ about $205 \mathrm{~kg}$ of carbon dioxide is being emitted into the atmosphere.

Environmental reasons urge us to find more efficient ways in converting and utilizing the energy resources. From the environment point of view, there is now almost universal scientific acceptance that profligate energy use is causing rapid and dangerous changes in the global climate. There is mounting evidence that the mean global temperature has increased over the period 1880 to 1985 by 0.5 to $0.7{ }^{\circ} \mathrm{C}$ (Hansen and Lebedeff, 1987). While surface air temperature (SAT) compilations shows that SAT has increased $1.2{ }^{\circ} \mathrm{C}$ last century. If a current climatic change trend continues, climate models predict that the 
average global temperature are likely to have risen by 4 to $6{ }^{\circ} \mathrm{C}$ by the end of 21 st century (Gaterell, 2005). As climate change progresses, all the other environmental problems are becoming worse and harder to solve. Therefore, a sustainable future requires worldwide efforts to prepare for new energy sources and a more efficient use of energy.

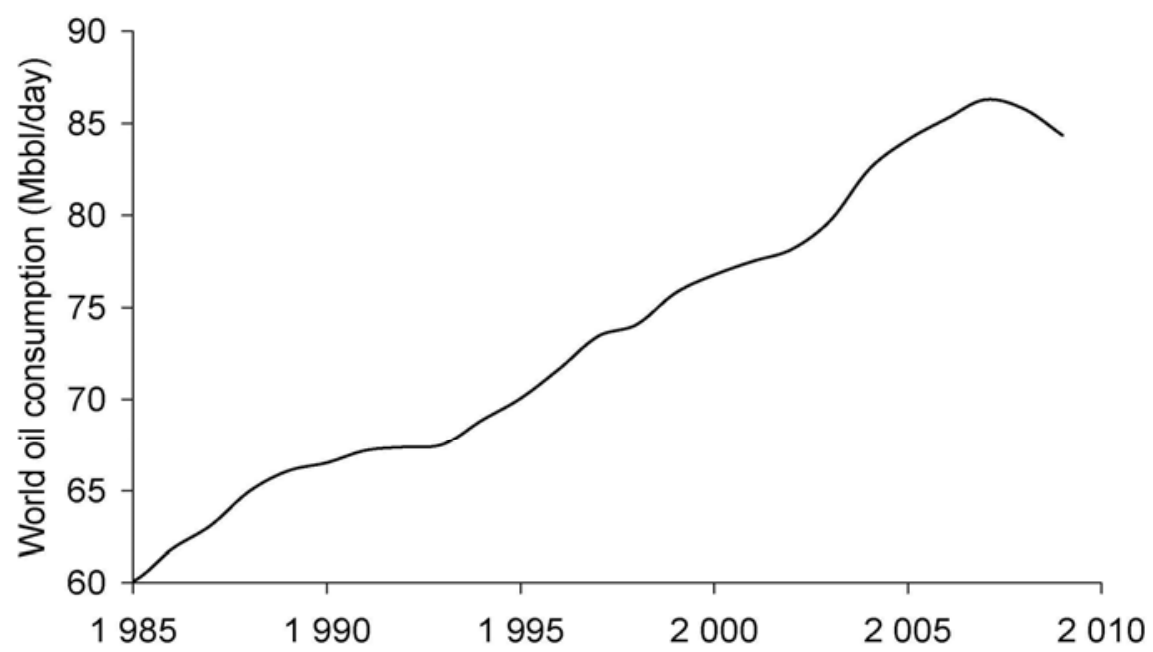

Fig. 1. World oil consumption.

Thanks to the awareness of the impact of global warming and its relationship with human activities, there has been a growing interest in reducing fossil energy consumptions. Specifically, more efficient use of energy and increased use of renewable energy seem to be our main weapon against the ongoing global warming.

Heating and cooling in the industrial, commercial, and domestic sectors accounts for about $40-50 \%$ of the world's total delivered energy consumption (IEA, 2007, Seyboth et al., 2008). Although, buildings regulations aim to reduce the thermal loads of buildings, as the economic growth improves standards of living, the energy demand for heating and cooling is projected to increase. For example, in non-OECD nations, as developing nations mature, the amount of energy used in buildings sector is rapidly increasing. Consequently, the implementation of more efficient heating/cooling systems is of clear potential to save energy and environment. However, the use of renewable energy systems for heating and cooling applications has received relatively little attention compared with other applications such as renewable electricity or biofuels for transportation. Yet, renewable energy sources supply only around 2-3\% of annual global heating and cooling (EIA, 2010). It is worth mentioning that a century or more ago renewable energy accounted for almost $100 \%$. In other word, all current researches aim to approach what was the case in the past.

Nowadays, and due to its high thermal performance, the ground source heat pump (GSHP) has increasingly replaced conventional heating and cooling systems around the world. Such system extracts energy from a relatively cold source to be injected into the conditioned space in winter or alternatively, extracts energy from conditioned spaces to be injected into a relatively warm sink in summer. 
Current work emphasizes the importance of using ground source heat pumps in reaching towards the renewable energy goals of climate change mitigation, and reduced environmental impacts.

\section{Principle of GSHP systems}

The ground source heat pump (GSHP) system are also known as ground coupled heat pump (GCHP), borehole systems or borehole thermal energy storage (BTES), and shallow geothermal system. Due to its high thermal performance, the ground source heat pump (GSHP) have increasingly replaced conventional heating and cooling systems around the world (IEA, 2007, Hepbasli, 2005, De Swardt and Meyer, 2001). Essentially GSHP systems refer to a combination of a heat pump and a system for exchanging heat from the ground. The GSHPs move heat from the ground to heat homes in the winter or alternatively, move heat from the homes to the ground to cool them in the summer. This heat transfer process is achieved by circulating a heat carrier (water or a water-antifreeze mixture) between a ground heat exchanger (GHE) and heat pump. The GHE is a pipe (usually of plastic) buried vertically or horizontally under the ground surface, Fig. 2 (Sanner et al., 2003). At the beginning of 2010 the totally installed GSHP capacity in the world was 50,583 MW producing 121,696 GWh/year with capacity factor and annual grow rate of 0.27 and $12.3 \%$, respectively (Lund et al., 2010).

Heating mode: In this case, the GHE and the heat pump evaporator are connected together and the heat pump moves the heat from the ground into the conditioned space. The liquid of relatively low temperature is pumped through the GHE, collecting heat from the surrounding ground, and into the heat pump. Since the temperature of extracted liquid, which is around mean annual air temperature, is not suitable to be used directly for heating purpose, heat pump elevates the temperature to a suitable level $\left(30-45{ }^{\circ} \mathrm{C}\right)$ before it is submitted to a distribution system.

Cooling mode: In this case, the GHE and the heat pump condenser are connected together and heat pump moves the heat from the conditioned space into the ground. The liquid of relatively high temperature is pumped through the GHE, dispersing heat into the surrounding ground, and into the heat pump.

As known, heat transfers from a warmer object to a colder one. Heat, as stated by the second law of thermodynamics, cannot spontaneously flow from a colder location to a hotter area unless work is done. The heat pump is simply a device for absorbing heat from one place and transporting it to another of relatively lower temperature. So, such device can be used to maintain a space temperature at desired level by removing unwanted heat (e.g. a fridge or air conditioning unit) or to transport heat to where it is wanted (space or water heating). In space conditioning application, heat pump system is composed of an indoor unite and an outdoor unite and the task of the heat pump is to transfer heat from one unite to the other. In order to keep inside temperature at comfort level in the winter, for example, the heat pump absorbs heat from outdoor and expels it into building. In the summer the reversed process occurs, i.e. the heat pump moves heat from indoor and expels it to outside.

The temperature difference between the indoor unite and outdoor unite is referred to as temperature lift. This temperature plays a major role in determining the coefficient of performance of heat pump ( $\mathrm{COP}=$ delivered energy/driving energy). A smaller temperature 

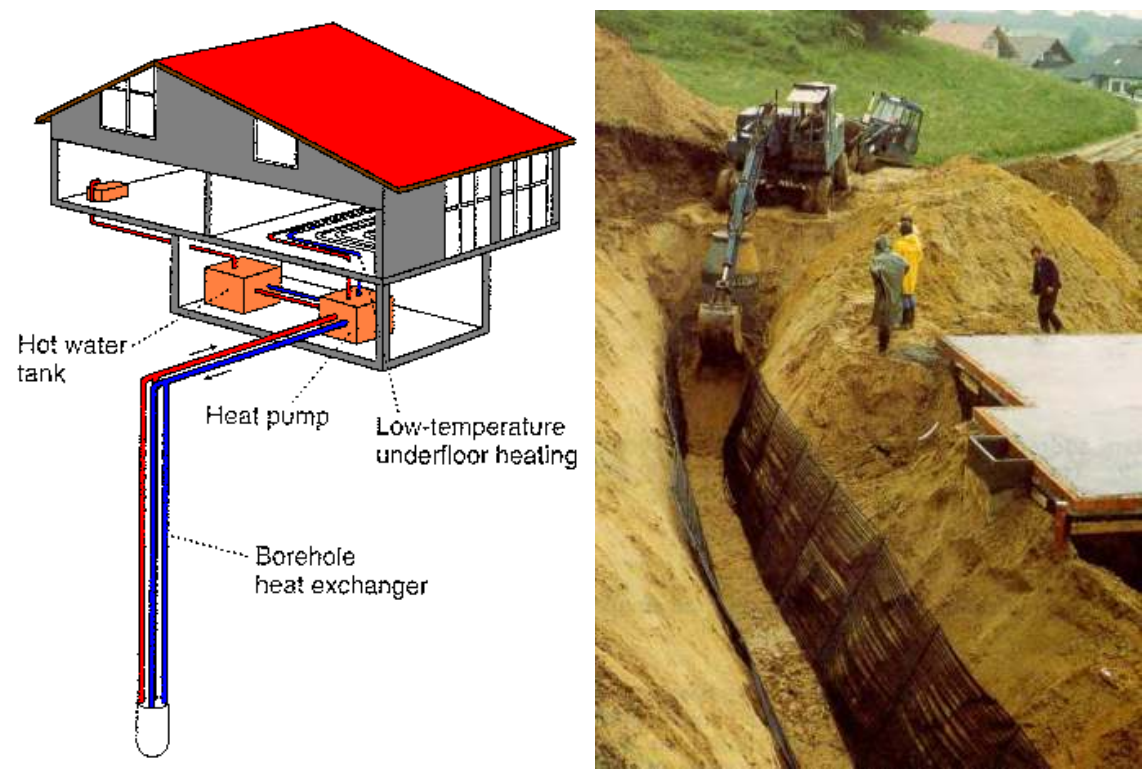

Fig. 2. Typical application of ground source heat pump system (Sanner et al., 2003).

lift results in a better COP. More specifically, extracting heat from a warmer medium during the heating season and injecting heat into a colder medium during cooling season leads to a better COP and, consequently, less energy use.

Fig.3 shows a schematic illustration of the components of assumed system as well as the thermodynamic cycle on diagrams temperature-entropy and pressure-enthalpy. Many techniques have been recently proposed in order to improve the cycle performance, more details are given by Wang, 2000, Chap.9 (Wang, 2000). In the current work, a heat exchanger has been added between the suction line and liquid line.

Like a heat engine but operating in reverse, the thermodynamics of the cycle can be analyzed on diagrams. In general COP is defined as the ratio between the delivered capacity and compressor capacity (Wang, 2000):

$$
\begin{aligned}
& C O P_{c}=\frac{Q_{c}}{W c p} \\
& C O P_{h}=\frac{Q_{h}}{W c p}
\end{aligned}
$$

Where $Q_{h}, Q_{c}$, and $W_{c p}$ represent the heating, cooling, and compressor capacity, respectively. 
As shown in the Fig. 3, the heat exchanging operations in the evaporator and the condenser occurs at constant pressure processes (isobar). The compression process in the compressor befall at isentropic process theoretically, while the expansion operation in the expansion valve occurs at adiabatic process. With these in mind, as per the thermodynamics rules, the terms of Eq.1 and Eq. 2 might be calculated as follows:

$$
\begin{gathered}
Q_{h}=m \cdot\left(h_{3}-h_{4}\right) \\
Q_{c}=m \cdot\left(h_{7}-h_{6}\right) \\
W_{C P}=m \cdot\left(h_{2}-h_{1}\right)
\end{gathered}
$$

Where, $h$ and $m$ represent enthalpy and refrigerant mass flow rate, respectively (see Fig. 3).

In order to accomplish the calculations, the following assumptions were made:

- $\quad$ Refrigerant R22

- $\quad$ Pressure drop at inlet and outlet of the compressor was assumed $\mathrm{P}_{8}-\mathrm{P}_{1}=10$

- $\quad$ and $\mathrm{P}_{2}-\mathrm{P}_{3}=23 \mathrm{KPa}$ respectively, see Fig.3.

- The pressure drop through the pipe is negligible.

- The isentropic efficiency of the compressor is $80 \%$.

- There is no sub-cooling in the condenser or useless superheat in suction line.

- Thermal efficiency of the heat exchanger, which expresses how efficient the heat exchanger utilizes the temperature difference, is $90 \%$

- Heat loss factor of the compressor, i.e. ratio between heat loss of the compressor to the surroundings and the energy consumption of the compressor, is $15 \%$.

- Regarding to the internal unite of the heat pump, in wintertime the condensation temperature was assumed $38 \circ \mathrm{C}$. In summertime, the evaporation temperature was assumed $8{ }^{\circ} \mathrm{C}$.

- Heating/Cooling capacity assumed to be constant, thus a change in temperature will affect the flow rate of refrigerant through the cycle.

The calculation results are illustrated in Fig.4. Apparently, the COP of heating machine increases as the evaporation temperature rises. Likewise, the performance of cooling machine increases as the condensation temperature decreases.

The ground temperature below a certain depth is constant over the year. This depth depends on the thermal properties of the ground, but it is in range of 10-15 m, see section 3 below. Thus, the ground is warmer than the air during wintertime and colder than the air during the summertime. Therefore, use the ground instead of the air as heat source or as a heat sink for the heat pump results in smaller lift temperature and, consequently, better thermal performance. In addition to improve the COP, the relatively stable ground temperature means that GSHP systems, unlike ASHP, operate close to optimal design temperature thereby operating at a relatively constant capacity. It is good to mention here that in outdoor unite fan, in ASHP case, consumes more energy than that of the water pump in the GSHP case (De Swardt and Meyer, 2001). Therefore, the comparison would be even more favorable for the GSHP, if the fan energy consumption is considered in the COP calculation. 

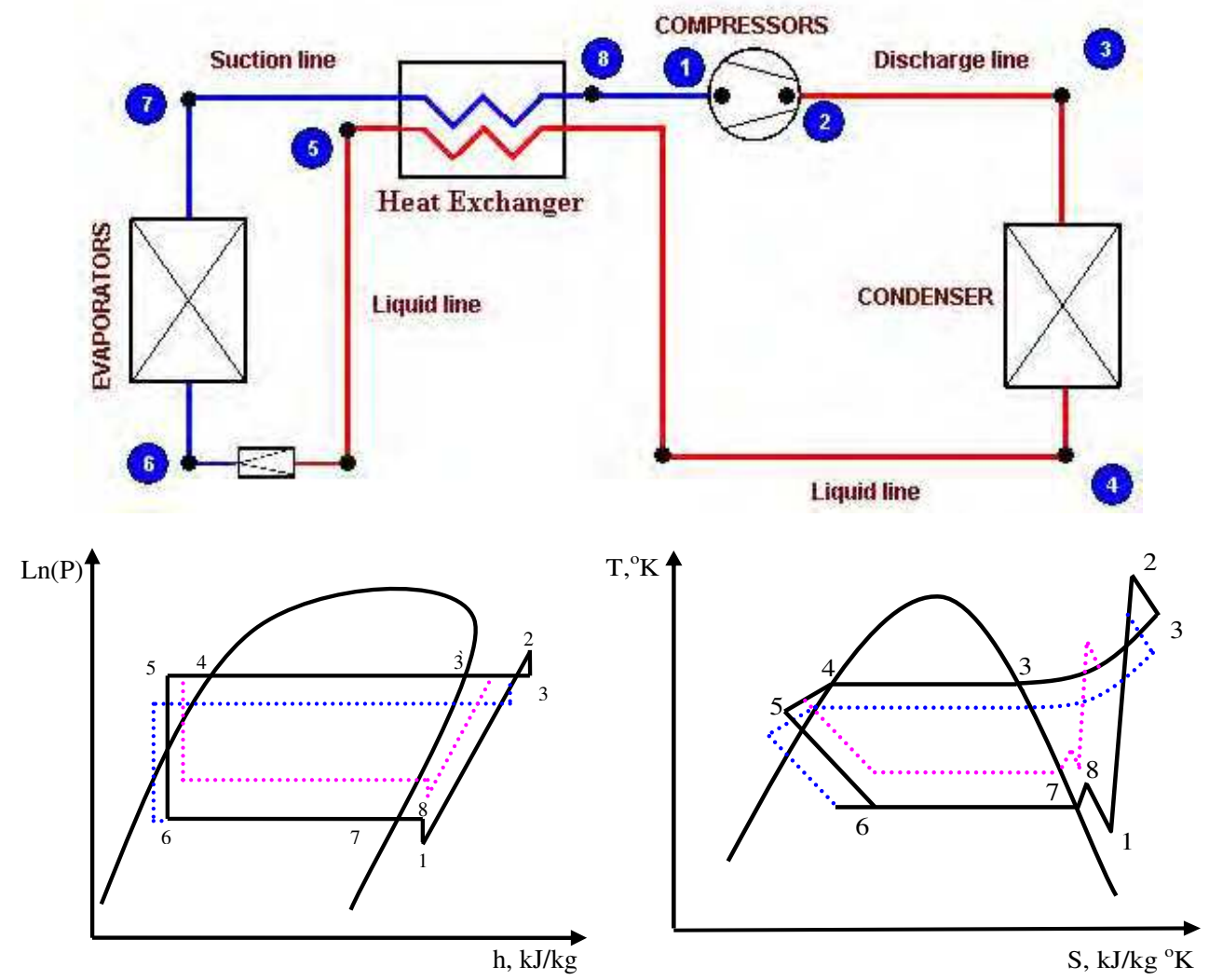

Fig. 3. Illustration of heat pump and the thermodynamic cycle on the LnP-h and T-S diagram.

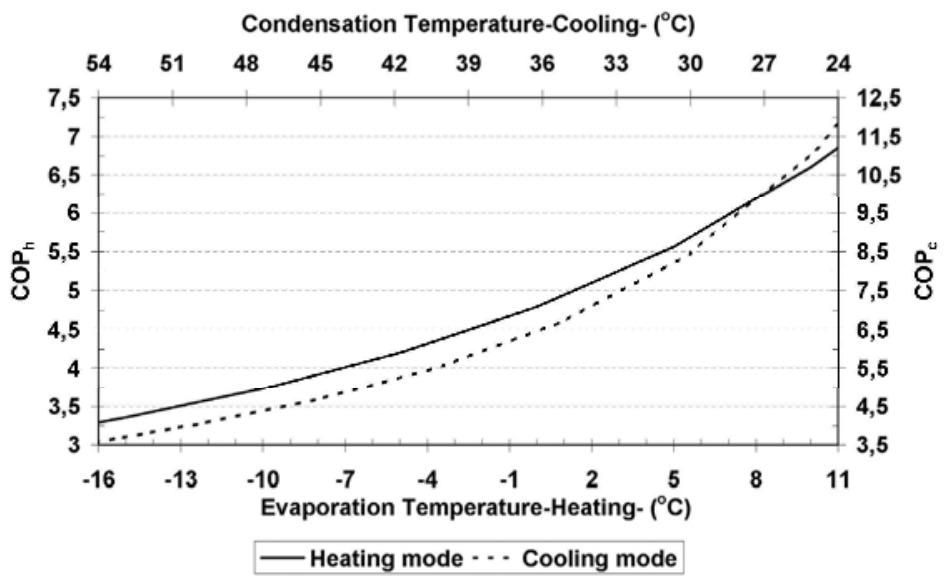

Fig. 4. Actual COP as a function of condensation / evaporation temperature. 


\section{Ground temperature}

The ambient air temperature over the year or the day can be treated as a sinusoidal function around its average value $\mathrm{Ta}$. This fluctuation might be expressed by:

$$
T(t)=T_{a}+A_{a} \cdot \cos \left(2 \pi \cdot \frac{t}{t_{o}}\right)
$$

Where $T(t)$ is air temperature at given time $t ; T_{a}$ is average air temperature for the period $t_{0}$, $A_{a}$ is the air temperature amplitude (half of the difference between the maximum and minimum temperatures for the period), $t_{\mathrm{o}}$ is the time for one complete cycle (day or year).

Apparently, air temperature fluctuation generates variations in the ground temperature. In order to find out a mathematical expression of ground temperature, the equation to be solved is the one-dimensional heat conduction equation. The mathematical formulation of this problem is given as:

$$
\frac{\partial^{2} T(z, t)}{\partial z^{2}}=\frac{1}{\alpha} \cdot \frac{\partial T(z, t)}{\partial t}
$$

Where $\alpha$ is the thermal diffusivity $\left(\mathrm{m}^{2} / \mathrm{s}\right), \mathrm{z}$ depth below the surface $(\mathrm{m}), \mathrm{t}$ is the time. Note that for oscillating temperature at the boundary, we do not need an initial condition The solution of Eq.12 can be found by Laplace transformation method (Carslaw and Jaeger, 1959):

$$
T(t, z)=T_{a}+A_{a} \cdot e^{-\frac{z}{d_{o}}} \cdot \cos \left(2 \pi \cdot \frac{t}{t_{o}}-\frac{z}{d_{o}}\right)
$$

Where $d_{o}$ is the penetration depth $(m)$, which is defined as the depth at which the temperature amplitude inside the material falls to 1 /e (about $37 \%$ ) of the air temperature at the surface:

$$
d_{0}=\sqrt{\frac{\alpha \cdot t_{0}}{\pi}}
$$

Fig.5 shows the underground temperature as function of the depth at different seasons of the year. As shown, below a certain depth, which depends on the thermal properties of the ground, the seasonal temperature fluctuations at ground surface disappears and ground temperatures is essentially constant throughout the year. In other word, for depth below a few meters ground is warmer than air during the winter and colder than the air during the summer.

Eq. 8 shows that ground temperature amplitude decreases exponentially with distance from the surface at a rate dictated by the periodic time, mathematically we can write:

$$
A_{g}=A_{a} \cdot e^{\frac{-z}{d_{o}}}
$$

Where $\mathrm{A}_{\mathrm{g}}$ is ground temperature amplitude $\left({ }^{\circ} \mathrm{C}\right)$. 
In addition, Eq. 8 shows that there is a time lag between the ground and air oscillating temperature. In other words, the maximum or minimum ground temperature occurs later than the corresponding values at the surface. From the cosine term in Eq. 8 one can conclude that the time lag increasing linearly with depth. The shifting time, $\varphi$, between surface and the ground at a given depth $\mathrm{z}$ is:

$$
\varphi=t_{2}-t_{1}=\frac{z}{2} \cdot \sqrt{\frac{C \cdot t_{0}}{\pi \cdot \lambda}}
$$

Indeed, change in temperature of ambient air results in change in the undisturbed ground temperature. Measurements of borehole temperature depth profile (BTDP) evidently show that there are temperature deviations from the linear steady-state ground temperature in the upper sections of boreholes (Goto, 2010, Harris and Chapman, 1997, Lachenbruch and Marshall, 1986, Guillou-Frottier et al., 1998). Mathematical models have been used to simulate the change in ground temperature due to GW. Kharseh derived a new equation that gives the ground temperature increase in areas where the surface warming is known (Kharseh, 2011). The suggested solution is more user-friendly than other solutions. The derived equation was used to determine the average change of ground temperature over a certain depth and therefore the heat retained by a column of earth during the warming period. This average change of ground temperature is of great importance in the borehole system.

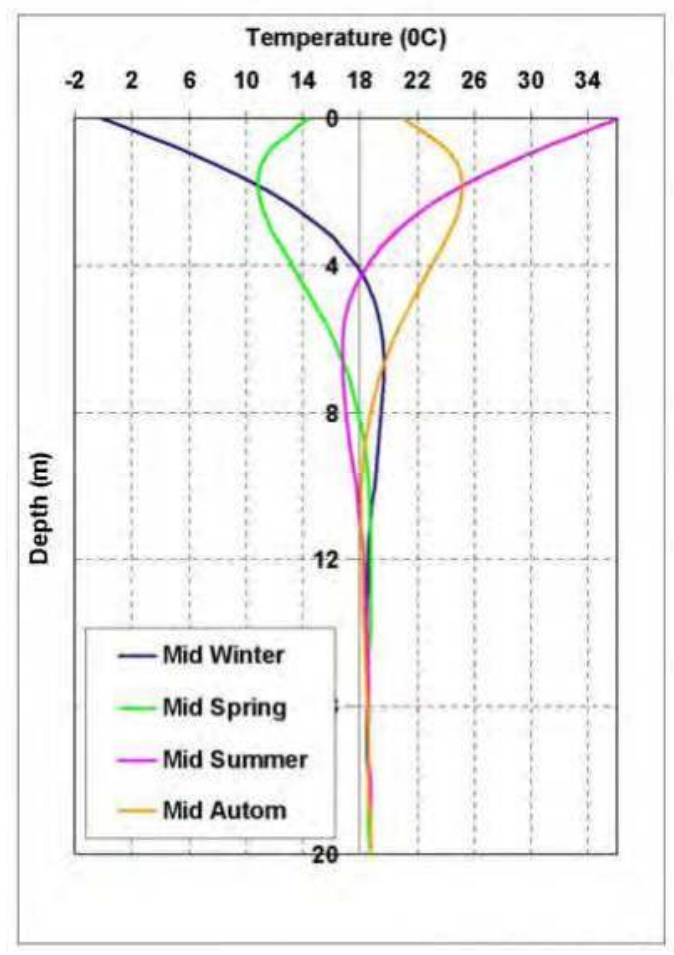

Fig. 5. Temperature profile through the ground. 


\section{Ground source heat pump systems and energy saving}

\subsection{Case study - the Kharseh chicken farm}

The Kharseh chicken farm in Hama, Syria, was selected as a study case to show the contribution of ground source heat pumps in saving energy consumption of heating and cooling system. Even though the annual mean temperature in Syria is $15-18{ }^{\circ} \mathrm{C}$, heating of such farm consumes considerable amounts of energy. The reason is that the air temperature is close to freezing during three winter months and that chickens require a relatively high temperature, $21-35^{\circ} \mathrm{C}$, depending on chickens' age as seen in Table. 1.

\begin{tabular}{|c|c|}
\hline Age of chicken & $\begin{array}{c}\text { Temperature at } \\
0.10-0.15 \mathrm{~m} \text { level }\end{array}$ \\
\hline (weeks) & $\left({ }^{\circ} \mathrm{C}\right)$ \\
\hline 1 & 35 \\
\hline 2 & 32 \\
\hline 3 & 29 \\
\hline 4 & 27 \\
\hline 5 & 24 \\
\hline 6 (fully grown) & 21 \\
\hline
\end{tabular}

Table 1. Appropriate indoor temperature in chicken farms.

The chicken hangar is placed parallel to the main wind direction has a floor area of $500 \mathrm{~m}^{2}$ $(50 \mathrm{~m} \times 10 \mathrm{~m})$ in E-W direction. The total window area is $24 \mathrm{~m}^{2}$.

\subsection{Heating/cooling demand}

The mean heating load composed of heat losses through the external walls and ventilation, while cooling load composed of heat gained through external walls, ventilation, solar radiation, and heat released by chickens. In current work the degree-hour method was used to estimate the thermal demand of the hangar (Durmayaz et al., 2000) using following assumptions:

- External wall's area, of thermal resistance $0.45 \mathrm{~K} . \mathrm{m}^{2} / \mathrm{W}$, is $336 \mathrm{~m}^{2}$

- Floor and ceiling area, of thermal resistance 5 and $0.45 \mathrm{~K} \cdot \mathrm{m}^{2} / \mathrm{W}$, respectively, is $500 \mathrm{~m}^{2}$

- Windows's area, of thermal resistance $0.2 \mathrm{~K} . \mathrm{m}^{2} / \mathrm{W}$, is $24 \mathrm{~m}^{2}$

- Ventilation rate $20 \mathrm{~m}^{3} / \mathrm{m}^{2}, \mathrm{~h}$ (ventilated area of chicken farm varies with chicken age)

- Heat release from chickens: $50 \mathrm{~W} / \mathrm{m}^{2}$ (varies with age)

- The capacity of the hangar is 5 cycles/year of 55 days the period of each cycle life. This mean that the hangar will be occupied $75 \%$ out of the entire year.

- During their first day, the chickens occupy about $85 \mathrm{~m}^{2}$ of the building. This area is increased $14 \mathrm{~m}^{2}$ per day until they occupy the entire area of the hangar after about one month. This mean the average occupied are during one cycle is $77 \%$ out of whole hangar's area. 
- Heating season is 6 months, while cooling season is 4 months.

- $10 \mathrm{~h}$ of cooling and 24 hours of heating are required per a day during summer and winter, respectively.

Using these assumptions, the total heat loss coefficient of the hangar, $\mathrm{L}(\mathrm{W} / \mathrm{K})$, can be calculated as follow:

$$
L=\frac{\left(\rho C_{p}\right)_{a i r} \cdot I \cdot V}{3600}+\sum U \cdot A
$$

Finally, annual heating demand, $\mathrm{Q}_{\mathrm{h}}(\mathrm{MWh})$, is

$$
Q_{h}=\frac{L \cdot D H h-50 \cdot 500 \cdot 24 \cdot 30 \cdot 6}{10^{6}}
$$

While the annual cooling demand, $\mathrm{Q}_{\mathrm{c}}(\mathrm{MWh})$, is

$$
Q_{c}=\frac{L \cdot D H c+50 \cdot 500 \cdot 10 \cdot 30 \cdot 4}{10^{6}}
$$

Where DHh and DHc is the total number of degree-hours of heating and cooling, respectively, which can be calculated as follow:

$$
D H h=\sum_{j=1}^{N}\left(T_{i}-T_{o}\right)_{j} \quad \text { when is } \quad T_{o} \leq T_{b}
$$

While for cooling (DHc)

$$
\text { DHc }=\sum_{j=1}^{K}\left(T_{o}-T_{i}\right)_{j} \quad \text { when is } \quad T_{o} \geq T_{b}
$$

Where $T_{b}$ is the base temperature and $T_{i}$ represents the indoor design temperature, $T_{o}$ is the hourly ambient air temperature measured at a meteorology station, $\mathrm{N}$ is the number of hours providing the condition of $T_{0} \leq T_{b}$ in a heating season while $K$ is the number of hours providing the condition of $T_{0} \geq T_{b}$ in a cooling season. In current work, and due to considering the big internal load, base temperature was assumed to be equal to $T_{i}$. Since the indoor temperature varies with the time during chickens cycle, the indoor temperature was assumed to be constant during one cycle and equals the average temperature i.e. $\mathrm{T}_{\mathrm{i}}=28{ }^{\circ} \mathrm{C}$. Fig. 6 shows that the estimated total annual heating demand is $230 \mathrm{MWh}$ while the corresponding cooling demand is $33 \mathrm{MWh}$.

In order to determine the maximum required heating and cooling capacity, the required heating/cooling power as the chickens grow during the hottest and coldest period of the year were calculate. As shown in Fig. 7, during heating season, due to lowering the appropriate indoor temperature with age and due to increase the occupied area, the heating power increases with time until it peaks in the middle of the chickens' life cycle. This peak demand does not occur during the cooling season. The calculations showed that the maximum required heating and cooling capacity are $113 \mathrm{~kW}$ and $119 \mathrm{~kW}$, respectively. 


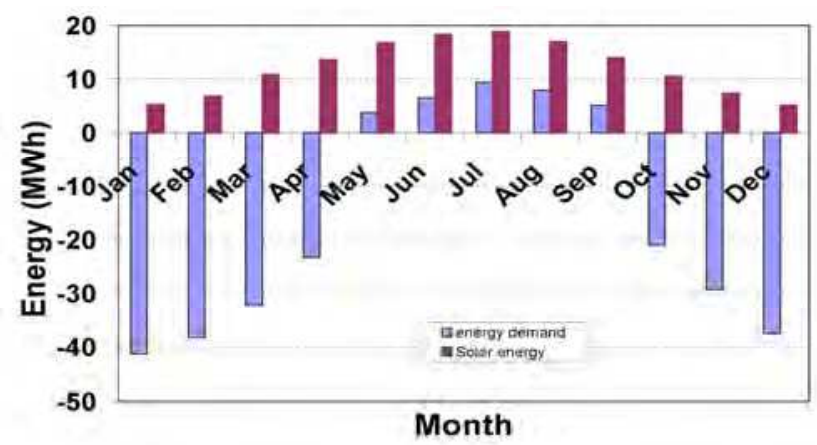

Fig. 6. Monthly heating/cooling demand and solar yield.

It should be noted that in Kharseh, 2009 the German DIN was used for the same aim. Therefore there is a small different in estimated thermal demand of the hangar.

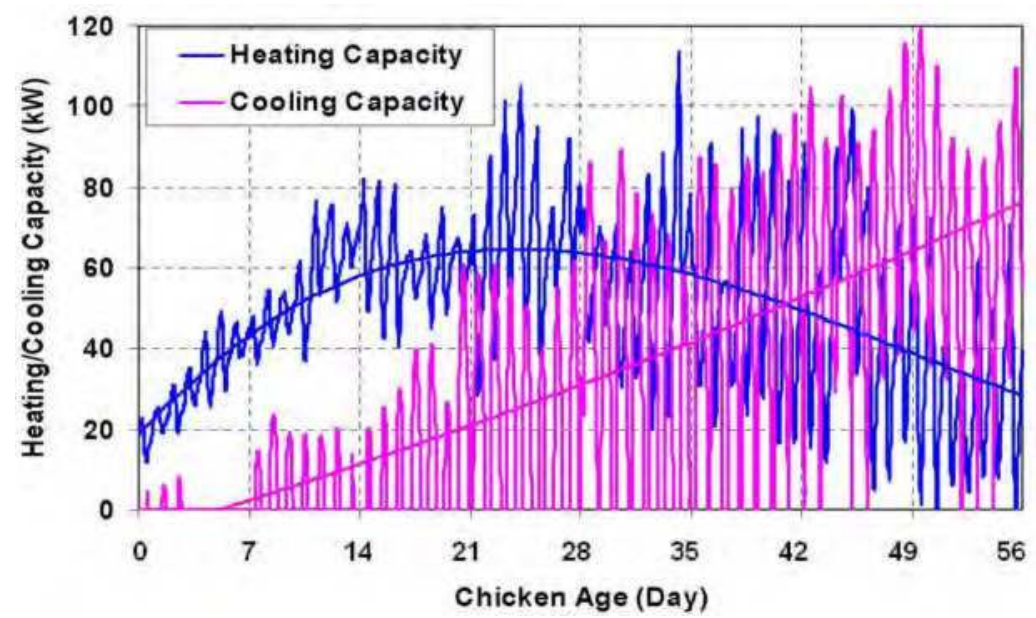

Fig. 7. Heating/cooling power as function of chicken age for one complete cycle during the hottest and coldest period.

\subsection{System design and simulated operation}

The EED (Earth Energy Design) model(EED, 2008) was used in pre-designing required borehole system to meet to estimated heating/cooling load at given conditions.

\subsubsection{Borehole system}

Specific data of the borehole system are given below:

- Number of boreholes: 10

- Borehole Diameter: $0.11 \mathrm{~m}$

- Borehole Depth: 120 m 
- Volumetric heat capacity: $2.16 \mathrm{MJ} / \mathrm{m}^{3} \cdot \mathrm{K}$

- Ground thermal conductivity: $3.5 \mathrm{~W} / \mathrm{m} . \mathrm{K}$

- Drilling Configuration: open rectangle $175(3 \times 4)$

- Borehole Spacing: $6 \mathrm{~m}$.

- Borehole installation: Polyethylene U-pipe

- Fluid flow rate: $0.510^{-3} \mathrm{~m}^{3} / \mathrm{s}$, borehole.

To keep the borehole temperature at steady state between the years extracted and injected heat from/to the ground were balanced by charging solar heat during the summer.

\subsection{Solar collector}

Since the annual heating demand of the hangar is much greater than annual cooling demand, which mean the energy extracted from the ground will be more than that injected into the ground, recharging the borehole filed by external energy resource is need. The amount of available solar energy in Syria means great potential for combined solar and GSHP systems. The estimated required solar collector area without considering heat yield from ground was:

$$
A=\frac{Q_{h} \cdot\left(1-\frac{1}{\operatorname{COP}_{h}}\right)-Q_{c} \cdot\left(1+\frac{1}{C O P c}\right)}{\eta \cdot \sigma}
$$

Where

$\mathrm{Qh}_{\mathrm{h}} \quad$ Heating demand (MWh)

$\mathrm{COP}_{\mathrm{h}}$ Coefficient of performance for heating (in this case $=5$ )

Qc Cooling demand (MWh)

$\mathrm{COP}_{\mathrm{c}} \quad$ Coefficient of performance for free cooling (in this case $=50$ )

$\sigma \quad$ Yearly sun yield (in this case $\sigma=1.973 \mathrm{MWh} / \mathrm{m} 2$ )

$\eta \quad$ Solar collector efficiency (in this case $\eta=0.86$ ).

In this case, the required solar collector area was $85 \mathrm{~m} 2$. The solar heat is directly used when needed while the rest of the heat is stored to be used later (Fig.8).

\subsection{Operation}

During the wintertime Fig.8, water is pumped from the borehole through the solar collector to increase its temperature. The temperature increase, which is only $0.8{ }^{\circ} \mathrm{C}$ during the winter, is considerably greater during the summer. The heat pump cools the water before it is again pumped through the borehole, where it will be warmed up. The extracted heat is emitted into the hangar. Fig.9 shows that the lowest extracted water temperature from borehole is $11.5{ }^{\circ} \mathrm{C}$. During summertime Fig.8, the ground temperature is cold enough for free cooling, so the water is pumped directly to the heat exchanger. Due to the heat exchange with indoor air, the water temperature will increase. After the heat exchanger, water passes though the solar collector and back to the borehole. Then, its temperature will decrease before pumped back to the hangar. Fig.9 shows that the highest extracted water temperature from borehole is $26.5 \circ \mathrm{C}$ 

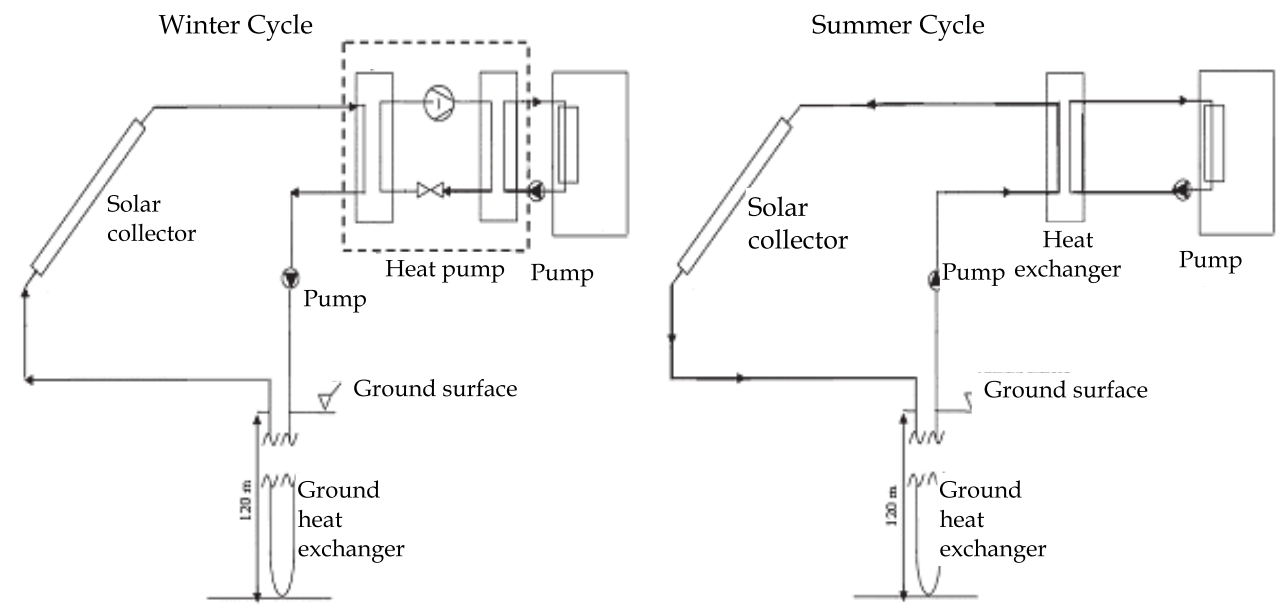

Fig. 8. Schematic of the solar coupled to ground source heat pump system.

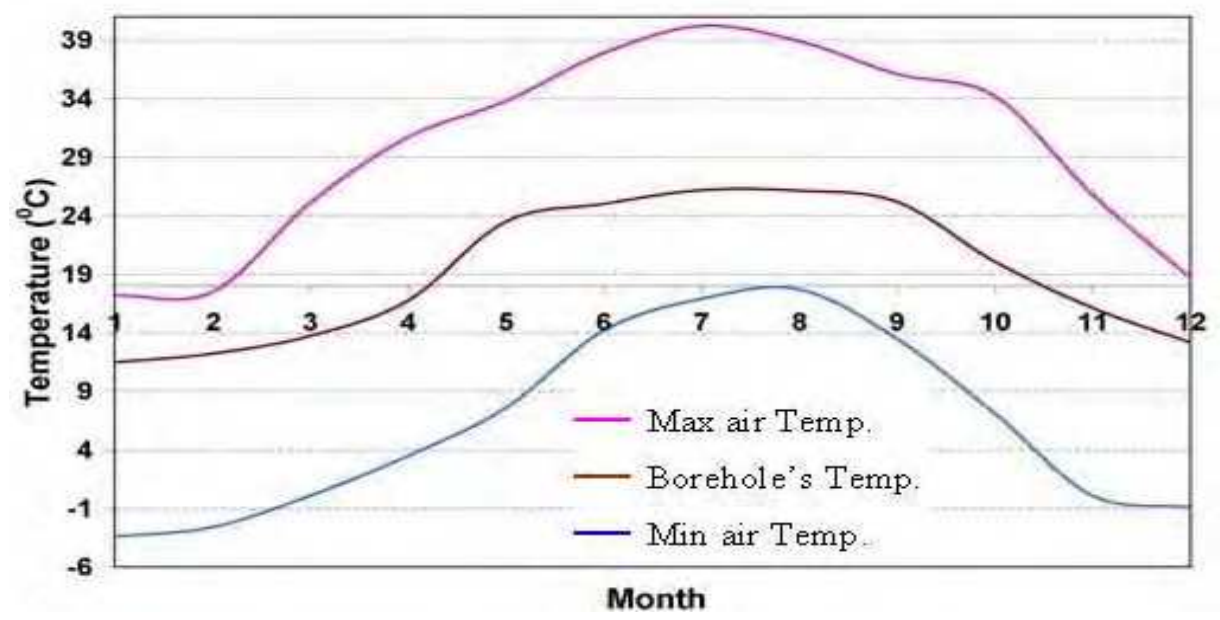

Fig. 9. Relevant temperatures for performed calculations. 


\section{Results and discussion}

Present study was performed to determine the potential of GSHP, with solar collectors, for heating and cooling purposes in the Middle East. The Kharseh chicken farm in Syria of area $500 \mathrm{~m}^{2}$ was chosen as a case study. The heating and cooling demands of the hangar were then used to estimate annual heating and cooling demands of the ideal chicken farm in Syria of area $200 \mathrm{~m}^{2}$. The calculations showed the following results:

- A typical average size chicken house in Syria requires $92 \mathrm{MWh}$ of heating and $13 \mathrm{MWh}$ of cooling. Required heating and cooling powers are $45.2 \mathrm{~kW}$ and $47.7 \mathrm{~kW}$, respectively, as shown in table 2 .

\begin{tabular}{|c|c|c|c|c|c|}
\hline \multicolumn{3}{|c|}{$\begin{array}{c}\text { Typical farm size } \\
\text { Floor area 200 } \mathrm{m}^{2}\end{array}$} & \multicolumn{3}{c|}{$\begin{array}{c}\text { Totally for } 13000 \text { farms } \\
\text { Floor area 2.6 } \mathrm{Mm}^{2}\end{array}$} \\
\hline $\begin{array}{c}\text { Meat } \\
\text { production } \\
\text { ton/year }\end{array}$ & $\begin{array}{c}\text { Heating } \\
\text { Energy } \\
\text { MWh/year }\end{array}$ & $\begin{array}{c}\text { Cooling } \\
\text { Energy } \\
\text { MWh/year }\end{array}$ & $\begin{array}{c}\text { Total energy } \\
\text { for heating } \\
\text { GWh/y }\end{array}$ & $\begin{array}{c}\text { Total energy } \\
\text { for cooling } \\
\text { GWh/y }\end{array}$ & $\begin{array}{c}\text { Total Energy } \\
\text { GWh/year }\end{array}$ \\
\hline 13 & 92 & 13 & 1196 & 170 & 1366 \\
\hline
\end{tabular}

Table 2. Heating and cooling demand for chicken farms in Syria.

- $\quad 480 \mathrm{~m}$ of borehole with diameter $0.11 \mathrm{~m}$ and $34 \mathrm{~m}^{2}$ of a solar collector were required to supply the heating and cooling of the typical chicken farms in Syria. In this case, the maximum fluid temperature delivered from the boreholes is $26.5{ }^{\circ} \mathrm{C}$ in the summer while the minimum mean fluid temperature was $11.5{ }^{\circ} \mathrm{C}$ during the winter.

- Table 3 shows the operation costs of coal furnace heating system combined with ASHP for cooling issue, diesel furnace heating system combined with ASHP for cooling issue, ASHP for both heating and cooling issue, and suggested GSHP heating/cooling system. Using Fig. 4, we found the $\mathrm{COP}_{\mathrm{h}}$ and $\mathrm{COP}_{\mathrm{c}}$ for the ASHP are 4 and 4.3, respectively, while the corresponding values for GSHP are 6.2 and 10. The conversion efficiency of conventional heater was assumed $85 \%$. The calculations show that by using the GSHP, the annual operation costs can be reduced $38 \%, 69.2 \%$, and $79.7 \%$ compared to ASHP, coal heater combined with ASHP, and diesel heater combined with ASHP, respectively.

- Table 4 shows comparison between the required prime energy, i.e. tons of coal, of three different systems assuming the average annual efficiency of the power plant $32 \%$. As shown, using the GSHP, the amount of fuel required is reduced $38 \%$ compared to ASHP or $57.2 \%$ compared to coal heater combined with ASHP. In other words, by use GSHP in all chicken farms in Syria, the annual coal consumption can be reduced 107.6.103 ton compared to traditional existing system (coal heater combined with ASHP). Accordingly, the carbon dioxide emission can be reduced by the same percentages. 


\begin{tabular}{|c|c|c|c|c|c|}
\cline { 3 - 6 } \multicolumn{1}{c|}{} & \multirow{2}{*}{$\begin{array}{c}\text { Energy } \\
\text { demand } \\
\text { GWh/year }\end{array}$} & $\begin{array}{c}\text { GSHP } \\
3.5 \mathrm{SP} / \mathrm{kWh}\end{array}$ & $\begin{array}{c}\text { ASHP } \\
3.5 \mathrm{SP} / \mathrm{kWh}\end{array}$ & $\begin{array}{c}\text { Coal Heater } \\
8,141 \mathrm{kWh} / \mathrm{kg}, \\
13 \mathrm{SP} / \mathrm{kg}\end{array}$ & $\begin{array}{c}\text { Diesel Heater } \\
10,1 \mathrm{kWh} / 1 \\
25 \mathrm{SP} / \mathrm{L}\end{array}$ \\
\cline { 3 - 6 } & 1196 & $675(\mathrm{COP}=6.2)$ & $1047(\mathrm{COP}=4)$ & $2247(\mathrm{\eta}=0.85)$ & $3479(\mathrm{\eta}=0.85)$ \\
\hline Heating & 170 & $60(\mathrm{COP}=10)$ & $138(\mathrm{COP}=4.3)$ & $138(\mathrm{COP}=4.3)$ & $138(\mathrm{COP}=4.3)$ \\
\hline Cooling & 1366 & 735 & 1185 & 2385 & 3617 \\
\hline Total & $\begin{array}{c}\text { Energy Cost } \\
\text { SP } / \mathrm{kWh}\end{array}$ & 0.54 & 0.87 & 1.75 & 2.65 \\
\hline
\end{tabular}

Table 3. Comparison between different heating/cooling systems for a typical chicken farm.

\begin{tabular}{|c|c|c|}
\hline System & $\begin{array}{c}\text { Required prime } \\
\text { Energy GWh/y }\end{array}$ & $\begin{array}{c}\text { Required Coal } \\
\left(10^{3} \text { ton }\right)\end{array}$ \\
\hline GSHP & 210 & 80.6 \\
\hline ASHP & 338 & 130 \\
\hline $\begin{array}{c}\text { Coal Heater } \\
\text { with ASHP }\end{array}$ & 1446 & 188.2 \\
\hline
\end{tabular}

Table 4. comparison between the required prime energy.

- $\quad$ The estimated installation cost of a borehole system for a typical chicken farm is $\$ 15000$. With current energy price in Syria the payback-time of GSHP is about 5.3, or 3 years compared to coal heater combined with ASHP, or diesel heater combined with ASHP, respectively.

\section{Conclusions}

The global energy oil production is unstable and will peak within a few years. Therefore, the energy prices are expected to rise and new energy systems are needed. In addition to this energy crisis the fossil fuels seems to be the main reason for climate change. There is a global political understanding that we need to replace fossil fuels by renewable energy systems in order to develop a stable and sustainable energy supply.

About half of the global energy consumption is used for space heating and space cooling systems. Ground source heat pump systems are considered as an energy system that can make huge contributions to reduce energy consumption and thereby save the environment. 


\section{Nomenclature}

$\mathrm{Q}_{\mathrm{c}} \quad$ cooling demand, (MWh)

$\mathrm{Q}_{\mathrm{h}} \quad$ heating demand, (MWh)

$\mathrm{W}_{\mathrm{cp}} \quad$ compressor capacity, $(\mathrm{kW})$

$\mathrm{COP}_{\mathrm{c}}$ coefficient of performance of cooling mode, (dimensionless)

$\mathrm{COP}_{h}$ coefficient of performance of heating mode, (dimensionless)

h enthalpy, (kJ/kg.K)

$\mathrm{P}$ pressure, $(\mathrm{Pa})$

$\mathrm{m} \quad$ refrigerant mass flow rate, $(\mathrm{kg} / \mathrm{s})$

$\mathrm{T}(\mathrm{t}) \quad$ air temperature at given time $\mathrm{t},(\mathrm{K})$

$\mathrm{T}_{\mathrm{a}} \quad$ average air temperature, $(\mathrm{K})$

$\mathrm{A}_{\mathrm{a}} \quad$ the air temperature amplitude, $(\mathrm{K})$

$\mathrm{A}_{\mathrm{g}} \quad$ ground temperature amplitude, (K).

$t_{0} \quad$ the time for one complete cycle (day or year) of air temperature variation

$\mathrm{z} \quad$ depth below the surface, $(\mathrm{m})$

a ground thermal diffusivity, $\left(\mathrm{m}^{2} / \mathrm{s}\right)$

$\mathrm{d}_{\mathrm{o}} \quad$ penetration depth, $(\mathrm{m})$

$\varphi \quad$ shifting time between the air and the ground temperatures variation,(s)

DH degree-hour, (h.K)

$\mathrm{CDH}$ cooling degree-hour, (h.K)

$\mathrm{HDH}$ heating degree-hour, (h.K)

$\mathrm{L}$ total heat loss coefficient of building, $(\mathrm{W} / \mathrm{K})$

$\mathrm{T}_{\mathrm{b}} \quad$ base temperature, $(\mathrm{K})$

$\mathrm{T}_{\mathrm{o}} \quad$ outdoor temperature, $(\mathrm{K})$

Min T minimum fluid temperature extracted from the borehole, $(\mathrm{K})$

Max $\mathrm{T}$ maximum fluid temperature extracted from the borehole, $(\mathrm{K})$

$\sigma \quad$ Yearly sun yield, $\left(\mathrm{kWh} / \mathrm{m}^{2}\right)$

$\eta \quad$ Solar collector efficiency

\section{References}

Carslaw, H. S. \& Jaeger, J. C. 1959. Conduction of heat in solids, Oxford: Clarendon.

De Swardt, C. A. \& Meyer, J. P. 2001. A performance comparison between an air-source and a ground-source reversible heat pump. International Journal of Energy Research, 25, 899-910.

Durmayaz, A., Kadioglu, M. \& Sen, Z. 2000. An application of the degree-hours method to estimate the residential heating energy requirement and fuel consumption in Istanbul. Energy, 25, 1245-1256.

EED. 2008. Earth Energy Designer [Online]. Available: www.buildingphysics.com/earth1.htm [Accessed]. 
EIA. 2007. Energy Information Administration [Online]. Available: www.eia.doe.gov [Accessed].

EIA 2010. International Energy Outlook 2010. Washington.

Gaterell, M. R. 2005. The impact of climate change uncertainties on the performance of energy efficiency measures applied to dwellings. Energy and Buildings, 37, 982995.

Goto, S. 2010. Reconstruction of the 500-year ground surface temperature history of northern Awaji Island, southwest Japan, using a layered thermal property model. Physics of the earth and planetary interiors, 183, 435-446.

Guillou-Frottier, L., Mareschal, J.-C. \& Musset, J. 1998. Ground surface temperature history in central Canada inferred from 10 selected borehole temperature profiles. Journal of geophysical research, 103, 7385-7397.

Hansen, J. \& Lebedeff, S. 1987. Global Trends of Measured Surface Air-Temperature. Journal of geophysical research: Atmospheres, 92, 13345-13372.

Harris, R. N. \& Chapman, D. S. 1997. Borehole temperatures and a baseline for 20th-century global warming estimates. Science, 275, 1618-1621.

Hepbasli, A. 2005. Thermodynamic analysis of a ground-source heat pump system for district heating. International Journal Of Energy Research, 29, 671-687.

IEA 2007. Renewables For Heating And Cooling. Paris, France: International Energy Agency.

IEA 2010. International Energy Agency. Oil and Gas Markets. Paris, France.

Jabder, S. A. A., Amin, A. Z., Clini, C., Dixon, R., Eckhart, M., El-Ashry, M., Fakir, S., Gupta,

D. \& Haddouche, A. 2011. Renewables 2011 Global Status Report. Paris, France: Renewable Energy Policy Netwrok for the 21st Century.

Jaber, S. A. A., Amin, A. Z., Clini, C., Dixon, R., Eckhart, M., El-Ashry, M., Fakir, S., Gupta, D. \& Haddouche, A. 2011. Renewables 2011 Global Status Report. Paris, France: Renewable Energy Policy Netwrok for the 21st Century.

Kharseh, M. 2011. Ground Response to Global Warming. Journal of geophysical research, Submited.

Lachenbruch, A. H. \& Marshall, B. V. 1986. Changing Climate: Geothermal Evidence from Permafrost in the Alaskan Arctic. Science, 234, 689-696.

Lean, J. \& Rind, D. 2001. Earth's response to a variable sun. Science, 292, 234-236.

Lund, J. W., Freeston, D. H. \& Boyd, T. L. Year. Direct Utilization of Geothermal Energy 2010 Worldwide Review. In: World Geothermal Congress 2010, 25-29 April 2010 2010 Bali, Indonesia. 1-23.

Moomaw, W., Yamba, F., Kamimoto, M., Maurice, L., Nyboer, J., Urama, K. \& Weir, T. 2011. Introduction. In IPCC Special Report on Renewable Energy Sources and Climate Change Mitigation. Cambridge.

Nordell, B. 2003. Thermal pollution causes global warming. Global and planetary change, 38, 305-312.

Nordell, B. \& Gervet, B. 2009. Global energy accumulation and net heat emission. International Journal of Global Warming, 1, 373-391. 
Sanner, B., Constantine Karytsasb, Dimitrios Mendrinosb \& Rybachc, L. 2003. Current status of ground source heat pumps and underground thermal energy storage in Europe. Geothermics, 32, 579-588.

Seyboth, K., Beurskens, L., Langniss, O. \& Sims, R. E. H. 2008. Recognising the potential for renewable energy heating and cooling. Energy Policy, 36, 2460-2463.

Wang, S. K. 2000. Handbook of air conditioning and refrigeration, New York, McGraw Hill. 


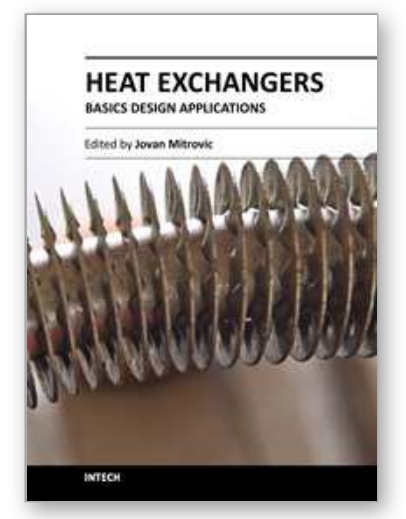

\author{
Heat Exchangers - Basics Design Applications \\ Edited by Dr. Jovan Mitrovic
}

ISBN 978-953-51-0278-6

Hard cover, 586 pages

Publisher InTech

Published online 09, March, 2012

Published in print edition March, 2012

Selecting and bringing together matter provided by specialists, this project offers comprehensive information on particular cases of heat exchangers. The selection was guided by actual and future demands of applied research and industry, mainly focusing on the efficient use and conversion energy in changing environment. Beside the questions of thermodynamic basics, the book addresses several important issues, such as conceptions, design, operations, fouling and cleaning of heat exchangers. It includes also storage of thermal energy and geothermal energy use, directly or by application of heat pumps. The contributions are thematically grouped in sections and the content of each section is introduced by summarising the main objectives of the encompassed chapters. The book is not necessarily intended to be an elementary source of the knowledge in the area it covers, but rather a mentor while pursuing detailed solutions of specific technical problems which face engineers and technicians engaged in research and development in the fields of heat transfer and heat exchangers.

\title{
How to reference
}

In order to correctly reference this scholarly work, feel free to copy and paste the following:

Mohamad Kharseh (2012). Ground-Source Heat Pumps and Energy Saving, Heat Exchangers - Basics Design Applications, Dr. Jovan Mitrovic (Ed.), ISBN: 978-953-51-0278-6, InTech, Available from:

http://www.intechopen.com/books/heat-exchangers-basics-design-applications/ground-source-heat-pumpsand-energy-saving

\section{INTECH}

open science | open minds

\section{InTech Europe}

University Campus STeP Ri

Slavka Krautzeka 83/A

51000 Rijeka, Croatia

Phone: +385 (51) 770447

Fax: +385 (51) 686166

www.intechopen.com

\section{InTech China}

Unit 405, Office Block, Hotel Equatorial Shanghai

No.65, Yan An Road (West), Shanghai, 200040, China

中国上海市延安西路 65 号上海国际贵都大饭店办公楼 405 单元

Phone: +86-21-62489820

Fax: $+86-21-62489821$ 
(C) 2012 The Author(s). Licensee IntechOpen. This is an open access article distributed under the terms of the Creative Commons Attribution 3.0 License, which permits unrestricted use, distribution, and reproduction in any medium, provided the original work is properly cited. 